\title{
The Pedagogical Practices of an Immigrant Parent: Maintaining Heritage Language in the Home Context
}

\author{
Emma Chen
}

\begin{abstract}
The maintenance of heritage language is essential to immigrant children's linguistic, cultural, and social development. While there is a large body of literature on heritage language, how heritage language is practiced at home remains largely unknown. Engaging in an autobiographical narrative inquiry, I tell and retell stories of our pedagogical practices in the home context. I seek to bridge the research gap with new understandings of the "parent knowledge" that immigrant parents bring to bear in heritage language education. I invite you into my home and immigrant family's language journey to witness the efforts, challenges, and rewards of learning heritage language.
\end{abstract}

\section{Narrative Wonders}

My name is Molly.

It is my English name.

My mom, dad, and grandma call my name in Chinese.

It is very similar to my English name - sounds like Mao Li.

In Chinese, 猫力means Cat Power.

I love my name because I love puppies and kittens.

(Molly's conversation with her friends, 2019)

When I think about language and identity, I recall the days when our family first moved to Canada from China, and our older daughter Molly (who was two-and-a-half years old and then our only child) left her Chinese-speaking home for the first time and entered an English-speaking daycare by herself. I remember Molly saying she was scared of daycare and we found out, after a series of conversations with her, the "scary thing" that haunted her little mind about daycare was "English." The image of Molly sitting alone under the bunk bed in the daycare classroom, holding a soaked tissue and murmuring "Daddy and Mommy, Daddy and Mommy..." (the only two English words she knew then), when we picked her up in the afternoons, will stay with me forever.

Then, one day, Molly was unusually excited when we got to the daycare and showed us her new best friend-a little girl who also spoke Chinese! The two of them chatted and laughed nonstop, in their home language, spreading joy and excitement all around the room. From that day forward, daycare became less scary and more interesting for her. With her friend's presence, Molly gradually opened up and reclaimed her confident, happy, and even talkative self! Her English skills also accelerated on a daily basis. I was happy to see her making sense of her surroundings with the aid of her home language, and then transfer the same concepts into the comprehension and expression in English. By the end of 
that year, Molly was basically an emergent bilingual who could communicate well in both languages. Being able to express herself in Chinese with her best friend bridged not only the Chinese and English languages, but also her Chinese and Canadian identities.

However, that is not to say she did not still face challenges. One day, Linda, the daycare staff member in Molly's room, asked me to stay and told me her "concerns" about Molly's behaviors. It turned out that Molly and her best friend sometimes spoke Chinese to each other in circle time and "it bothered the other kids because none of them could understand what they were saying." The girls did not stop speaking Chinese after a few warnings and "continued to form their closed group which other kids and the teachers couldn't get into." She stated that "it was a disruption of the group activities" and so they had to ask Molly and her friend to leave the group circle and sit in the reading corner by themselves (Personal communication with Linda, November 16, 2017).

I left the conversation with so many wonders. The daycare staff member with whom Molly had spent months learning, playing, and spending much of her days was obviously a good educator: caring about the young children, good at communicating with the parents, committed to early childhood education, and well liked by the children at the daycare. She was also one of the staff who held and comforted Molly during the most difficult first weeks. Why, then, did she struggle to see the challenges and difficulties for an immigrant child to navigate between two languages and cultures? What might it take to have the educators at this daycare awaken to the fact that children's opportunity to speak their home language, not only at home but also in other inviting and welcoming settings, holds tremendous meanings for immigrant children linguistically, culturally, and socially? What can I, as a parent, do at home for my child to maintain a positive language environment, to develop her heritage language skills, and to grow her love and confidence of speaking the language her family and ancestors also speak? How can I use the knowledge of language, culture, identity, and transition that I gained from my lived experiences in becoming an immigrant parent, to help my child flourish in two worlds?

My memory of that moment in Molly's daycare classroom lingered with me long after my living through it. Slipping backward and forward in time, I walked alongside (Pushor, 2015) my children to explore the maintenance of our heritage language in an English-dominated society. Inquiring into this experience afforded me the opportunity to "dwell in" (Polanyi, 1958), to both consciously experience and intelligently contemplate that which I was coming to know. It is through "dwelling in" whereby I can continue to shape and reshape my understanding of what it means for immigrant parents and immigrant children to maintain heritage language. While there is a large-and growing-body of literature on heritage language, few studies (Dixon \& Wu, 2014; Kang, 2013; Pham \& Tipton, 2018) have explored the specific strategies and practices that immigrant parents implement and the ways in which they integrate resources in the home context to support their bilingual children's heritage language maintenance and development. As a result, how heritage language is used, taught, and practiced in immigrant families' home settings remains largely unknown.

The purpose of this autobiographical narrative inquiry is to explore my pedagogical practices as an immigrant parent, in our home context, in order to make visible my parent knowledge (Pushor, 2015). 
The Pedagogical Practices of an Immigrant Parent: Maintaining Heritage Language in the Home Context

It is in considering how that knowledge may be laid alongside the knowledge of early childhood educators, in childcare centers and schools, that opportunities exist to enhance linguistic, cultural, and social experiences for young children.

\section{Narrative Inquiry as Research Methodology}

Many wonders and experiences shaped the life narratives of our family's first few years in this new land, a land in which sometimes we feel we are both standing-out and invisible. As Clandinin and Rosiek (2007) pointed out, "The focus of narrative inquiry is not only on individuals' experiences but also on the social, cultural and institutional narratives within which individuals' experiences are constituted, shaped, expressed, and enacted" (p. 42). In this autobiographical narrative inquiry methodology, I have been empowered to better confront, digest, and analyze these encounters.

One of the traits that draws me to autobiographical narrative inquiry is that it honors the significance of time and space, of the inquiry, of me as the inquirer, and of my children as constructors of our shared

learning experience into which I am inquiring. Just as narrative inquirers are strongly encouraged to remember that "participants are always in the midst of their lives and their lives are shaped by attending to the past, present, and unfolding social, cultural, institutional, linguistic, and familial narratives" (Clandinin \& Caine, 2013, p. 170), I explore the heritage language learning encounters with my children in the midst of our lives in the new country. These encounters of our family members have a past, present, and future. I enter this autobiographical narrative inquiry as an inquirer and a participant, and begin to engage in the living inquiry of our lived stories. Connelly and Clandinin (2006) describe a "living inquiry" as "a more difficult, time-consuming, intensive, and yet, more profound method to begin with participants' living" (p. 478). During the living and telling of our stories, I am able to see that I am changed as I retell our lived and told stories, and therefore may begin to relive our stories with a newly gained lens.

In these autobiographical narrative inquiries, I work to present our stories as in transition. In narrative inquiries, the key to understanding "place" is to recognize that "all events take place someplace" (Connelly \& Clandinin, 2006, p. 481), and that each place, whether constant or fleeting, has importance or significance. To gain perspective on the experiences of our family, I invite you to keep in mind that, as parents and children, we are living a storied experience on a new landscape in transition. "In narrative thinking, temporality is a central feature" (Clandinin \& Connelly, 2000, p. 29). Our living stories are fluid as the situations constantly evolve.

\section{Telling My Stories: Practicing Heritage Language at Home}

The daycare teacher's conversation with me about Molly's use of her heritage language called me to be attentive to my understanding of "parent knowledge" (Pushor, 2015) as an immigrant parent to bilingual children, Molly and her Canadian-born sister, Luna. As I struggled and explored our ways of teaching, learning, and playing at home, I came to understand, "[O]nly parents possess parent knowledge, the 
particular knowledge held and used by someone who nurtures children in the complex act of raising a child and in the complex context of a home and family" (p. 15). I was awakened to the realization that in our home, in our family, and in our lives, there are no other people who hold more knowledge of my daughters than me. I am the mother, the insider, the one who holds the parent knowledge gained from my lived experience with my daughters as I care for them, engage with them in play, interact with them with family and friends, transition my family to this new country, and, in all of this, explore with them languages and identities.

I know my children differently and more profoundly than anyone else in the world because of the uniqueness of our relationship_-a relationship that is inextricably intertwined, in physical and emotional ways (Pushor, 2015). Walking alongside my girls in the transition to a new country, I share my parent knowledge within our mother-daughter relationship and in the shared time, space, languages, and activities in our home-in singing songs, reading books, doing crafts, playing games; in connections during speaking our first language and the conversations back and forth in both English and Chinese; in sharing personal stories of mine before my children came into the world, and then stories of when they were babies.

With these understandings, I began a shared journey with my children of maintaining and developing Chinese-the language I inherited from my parents, and they from theirs; the language through which I feel a connection with thousands of years of my motherland's history and with billions of people who share traits similar to us. I spent time with Molly and Luna, alongside other close and extended family members - talking, playing, reading, writing, creating, laughing, and sometimes crying -in the home and community context. During the process, I kept a daily digital journal on social media, as a field text to track and document my observations and experiences about our home language learning. I am in the living, telling, reliving, retelling of our stories at home and in the community, co-composing field texts with my children in a relational way, for "relationships are a central way of making sense of the temporal and contextual aspects of narrative inquiry" (Clandinin, 2013, p. 34). As our natural learning process unfolds, I live and reflect on the lived experience everyday as a process of data analysis.

\section{Awakening to (Immigrant) Parent Knowledge}

Every human being is a holder of "funds of knowledge" (González et al., 2005, p. ix). It is the knowing that becomes part of who we are as we engage with the world and are changed by it (Polanyi, 1958). Elbaz (1981) conceptualized knowledge as "directed toward making sense of, and responding to, the various situations of" (p. 49) a particular role. In the role of an immigrant parent, I hold a particular fund of knowledge, that of "parent knowledge" (Pushor, 2015) that is grounded in and shaped by the foundational living experience of my personal journey; it is situated in time and space, enveloped within a broader social context, and influenced by my general theoretical orientation (Elbaz, 1981). My parent knowledge, like any other parent's, demonstrates temporal dimensions because it resides in "the person's past experience, in the person's present mind and body, and in the person's future plans and actions" (Connelly \& Clandinin, 1988, p. 25). 
The Pedagogical Practices of an Immigrant Parent: Maintaining Heritage Language in the Home Context

As I walked into the midst of my life in a new country, and I gained a new identity as an immigrant parent of bilingual children, I gradually accumulated an additional aspect to my existing parent knowledgeimmigrant parent knowledge (Guo, 2012). This immigrant parent knowledge arises out of my own educational background, my professional and personal experiences of interacting with schools in my country of origin, my current understanding of the host country's education system, and my struggles as an immigrant parent. It combines with my parent knowledge growing from both my past and present lived experiences with my daughters and my future aspirations for my children (Pushor, 2008). In telling her own stories, Khan (2018) pointed out a sad reality that immigrant parents and their knowledge are typically seen as deficit-based in the host society. My experience aims to tell a different story, through a capacity-based lens, of how immigrant parent knowledge helps enhance my children's language learning.

\section{Creating a Heritage Language-Rich Home Environment}

"A different language is a different version of life." - Federico Fellini (Cantwell, 1993)

Language is important to everyone. It is beyond a mere means of communication. It is part of who we are. For our family, Chinese and English are the two languages used to compose our daily narratives. Like many immigrant families living in Canada, English exists in a much larger world (e.g., schools, workplaces, grocery stores, media) while our heritage language lives within our community and mainly within our home settings. Roessingh (2014) pointed out that many immigrant children completely lose any and all developed language proficiency of their heritage language, due to the fact that heritage language is reserved only for basic oral communication purposes within a small community of family and friends. Over the years, I have witnessed that many children in the Chinese immigrant community spoke only English to their parents even when the conversations were initiated by the parents in Chinese. The home setting and the school landscape may be disconnected from one another, not only geographically, but also culturally, linguistically, and socially. Various home languages are excluded from the school's cultural repertoire, whereas prestigious languages such as English and French are highly valued (Agirdag, 2010). "[A]mong the children of immigrants, English emerged as an unequivocal winner in the struggle for their linguistic souls" (Suárez-Orozco, 2001, p. 136). It is critical, then, that instructional and pedagogical strategies preserve and enhance an immigrant child's heritage language and culture.

So, what can I do, as a parent of two immigrant children? While reviewing the literature in heritage language education, my attention was directed to our home setting. Home is a very private place, often the place in which family members are able to be their most authentic selves (Pushor, 2015). The intimate nature of home enables learning to happen in the most natural ways, particularly with children. I saw the relationship between the girls and me as fertile soil from which their learning would grow. Therefore, the first initiative I took to promote Chinese language learning was to create a home literacy environment, including daily conversations, inter-generational communications, bookshelves filled with picture books written in Chinese, multimedia resources in Chinese language, and fun ways of integrating their names into songs and lullabies.

LEARNing Landscapes | Spring 2021, Vol. 14 No. 1 | 33 
Conversations were a significant marker of our home literacy environment. Shneidman and Goldin-Meadow's (2012) cross-cultural study reinforced the staggering importance of daily oral input to a child's language development. As we went about our daily business together, engaged in getting dressed, taking baths, having meals, playing games, taking walks, and so forth, I tried to elaborate, explain, and encourage detailed conversations. Especially after Molly gradually mastered the art of the English language, I felt it was important to make Chinese visible as the language she was encouraged to use in our home context. During a bumpy flight to Vancouver last year, Molly sought comfort in my arms and said: “妈妈, 我的 耳朵里在刮风呢." The sentence can be roughly translated as, "Mommy, there is wind blowing in my ears." I instantly understood that she had clogged ears due to the pressure shift in the plane. I could not help but be amazed and touched by her extraordinarily poetic expression in our first language. Li (2006) showed us that when parents enforce a heritage-language-only policy at home, children tend to develop a more positive attitude toward and higher levels of proficiency in their first language. Such a "policy" was never forced on my children, for I wanted to keep their passion for speaking the Chinese language alive. The balance between encouragement and enforcement is indeed fine, but what a delight it was to hear the surprisingly charming phrases coming from the young ones, as they mastered the beauty of this ancient language. Every night before bed, I would say “我爱你I love you” to Luna. Instead of saying “我 爱你" back to me, she claimed, with her innocent yet frank voice, “爱我! " which means, "Love me!" For a one-and-half-year-old child, the conversion of personal pronouns in Chinese was a major achievement, a reflection of her engagement in our day-to-day language exchanges of speaking Chinese.

Inter-generational communications played an important role in Molly and Luna's heritage language development. Everyday communications with their grandmother, one of the primary caregivers who lives with us, helped promote the Chinese-only language commitment at home. Molly and Luna were well aware that "Grandma doesn't speak English," so they "consciously experience[d]" (Polanyi, 1958, p. 195) the switch of languages when they talked to Grandma. Another way in which Grandma passed on her knowledge of language and culture was through cooking and sharing food with the children, as they engaged in the process with her and conversed about making and enjoying authentic Chinese cuisine.

Books can be found everywhere in our house, including adult's and children's books, written in English and in Chinese. I intentionally made it visible that books were an important and normal part of our lives and purposefully modeled reading myself. The importance of repeated story reading and storytelling in both first and second languages has been highlighted in many studies (Avalos et al., 2007; Coyle \& Mora, 2018; Collins, 2005; Nunez, 2019; Roessingh, 2014; Strekalova-Hughes \& Wang, 2019). Uccelli and Páez (2007) showed a striking finding in their study examining Spanish-English bilingual children, "If children hear, engage and tell stories in Spanish with friends, family, or at school, the learned set of skills required to structure a story in Spanish could positively contribute to children's English narrative quality" (p. 234). Cummins (2017) also suggested that skills learned in a child's heritage language will transfer to the learning of a second language. Therefore, strengthening, supporting, and fostering a positive heritage language environment for immigrant children will create a solid foundation for their 
language development in English (Goldenberg et al., 2013). As an immigrant parent, I was attentive to the balance between the dominant language and heritage language. Like many immigrant parents, I held a palpable desire for my young children to learn English. I intuitively and consciously recognized English as the power code (Delpit, 1995) that my children needed to crack for their success in school and in life. Therefore, books and multimedia resources in both languages were introduced and encouraged.

Creating songs and lullabies with their names was another way I made learning heritage language fun. Lyrics with their own names drew their attention to listening and singing in Chinese. Ever since they were babies, each of them had an exclusive lullaby composed with Chinese sentences that rhymed with their names.

“这只小乘猫呀 (Hi dear baby cat)

现在要睡觉 (Now it's time to go to bed)

闭上大眼睛 (Close your big eyes)

一会儿就睡着 (Fall asleep really fast)"

(Molly's lullaby, 2014)

“妈妈的小露露 (Mommy's little Lulu)

不哭不哭哭 (Please don't cry)

妈妈的小露娜 (Mommy's little Luna)

睡觉睡觉啦 (Let's go to sleep)"

(Luna's lullaby, 2018)

Many researchers have pointed out that parents who demonstrate positive attitudes toward heritage language pose a strong influence on their children's attitudes and language proficiency (Hinton, 2001; Kondo-Brown, 2010; Luo \& Wiseman, 2000; Mills, 2001; Oh, 2003). Immigrant parents who attach importance to maintaining and developing heritage language and emphasize the need to continue using the language foster a positive environment for children to grow a passion for that language (Li, 2006). Children in a positive language environment have a higher chance of continued use of their heritage language, even after exposure to English, as compared with children living with parents who do not make these language efforts (Oh, 2003). It was apparent that the intimate moments I shared with Molly and Luna during singing lullabies in Chinese every night were ones that evoked interest in learning heritage language, and these moments also linked their sense of being loved to the language we shared within our home setting. Attentive language practices like this trace pieces of our unique and particular home language learning pedagogy. 


\section{So Much More Than Story Reading}

In ways that were reflective of my culture, context, personal knowledge, and beliefs, I began my children's language education immediately, by talking with them when they were newborn babies, singing songs, and reading/telling stories.

Children's picture books were my favorite, among the many means of introducing language. I loved picture books because they contained sophisticated real-life topics, short, simple, and child-friendly text, and visual information to help children convey ideas. Because I was also keenly aware of the fact that storybook exposure promotes language acquisition (Sénéchal \& LeFevre, 2002; Sénéchal et al., 1998), I intentionally made picture book reading a part of our language practice at home. For Molly and Luna, though, shared reading was never a "learning activity"; rather, it was a fun family time during which the three of us cuddled closely, sometimes under a warm blanket, sharing in our home language a book with lively pictures and vibrant colors. When I read those appealing stories that happened in ancient China, the modern Western world, or the magic imagination land, I could hear the beautiful Chinese sentences flowing in the air and then into my young children's ears and minds. I witnessed how they absorbed the language and knowledge passed through me from a large community, a rich culture, and the long history of our homeland. Molly, who is three years older than Luna, often took the responsibility of "teaching her little sister" by holding the book and reading to her-and by reading, I mean telling the stories imprinted in her tiny head after many story times with us. Pictures helped link the content and the words. I would deliberately point to the Chinese characters after I had read the same book a few times and knew they were familiar with the story lines, in order to introduce print in our home language. Given the complicated nature of Chinese print, I preferred this more natural way of gradually familiarizing them with the written language.

Following the young ones' lead, we extended and expanded existing story-reading language practice while engaging in picture books. The two sisters freely took initiative. Molly and Luna often applied their "wild imagination" (Conversation with Molly, 2019) to comprehend the stories and utilize the languages in the most creative ways. They showed me the transformative power of drawing, painting, crafting, music, dance, and performance, not only as a way of shaping new and deeper understandings of the stories, but also as a way of forming spaces with potential for traveling smoothly in and out of the webbed and interwoven Chinese and English language worlds. During roleplaying, after adopting the plots and characters in the stories, Molly and Luna tended to use both languages spontaneously and pragmatically. This "translanguaging" (Baker, 2001, p. 281) approach they used is common among bilingual and multilingual children and was encouraged in our home language learning activities. Such exchange and mixed-use of languages is beneficial for both heritage and dominant language development (Baker, 2001).

Real-life stories were the most beloved type of storytelling by Molly and Luna, given the very personal and particular nature of the home landscape. Among those real-life stories, one theme remained most popular: the days they were born. Many researchers have foregrounded the important link between heritage language and family literacy practices. Wong Fillmore (2000), and Scheele and colleagues 
The Pedagogical Practices of an Immigrant Parent: Maintaining Heritage Language in the Home Context

(2010) emphasized the importance of developing social capital by sharing past experiences and telling real-life stories to children. Gradually introducing increasingly more difficult vocabulary and complex expressions helps with heritage language development (Vaish, 2019). We must have told, retold, and acted out their birth stories hundreds of times during the course of three years. From the moment mom felt a tummy ache, to the time doctors and nurses took mom in; from how to breathe during labor, to cutting the umbilical cord; from holding the baby in mom's arms for the first time, to feeding and rocking the crying baby to calm her down, we lived and relived those moments through repeated storytelling and acting. It was in these times that they learned to listen to, participate in, and understand narrative discourse. Enacting their birth stories created a path to more sophisticated use of the Chinese language, and contributed to deeply bonding relationships with me and with each other. Engaging in real-life storytelling and story-acting resulted in positive effects in intellectual, social, emotional, and linguistic development (Mokhtar et al., 2011) for Molly and Luna. The process of telling and acting true stories that involved memory and social skills (Glonek \& King, 2014) also employed physical as well as narrative aspects that provided a significant foundation for language development.

\section{Nurturing Passion for Early Writing}

Play often motivates children to expand their language knowledge and practice their literacy skills (Ewing et al., 2016). One of our favorite language games was "composing" stories using Chinese character blocks. Each of us took a few blocks, arranged them in a row, and told a story based on the words (or pictures in Molly and Luna's case) on the blocks. It was a magical time filled with imagination, silliness, and laughter, as well as free exploration and navigation of the language, both orally and visually. Games like this helped the girls open the door to the wonderful world of Chinese characters, which led to a playful start of early writing.

"Emergent writing is young children's first attempts at the writing process" (Byington \& Kim, 2017, p. 74). By making sketches and symbolic marks that reflect their thoughts and ideas, children as young as two years old start imitating the act of writing (Rowe \& Neitzel, 2010; Dennis \& Votteler, 2013). The big blackboard wall in the living room was our shared writing board. I enjoyed making to-do lists and leaving notes on it while Molly and Luna turned the blackboard into their canvas for scribbling, drawing, and early writing. We exchanged ideas and messages in written Chinese. Some were easy to read and some were not, but every word written down was encouraged and appreciated. In addition to the blackboard notes, Molly and I also kept two journals - a happy journal for cherishing joyful memories and a crying journal for expressing her negative emotions in a healthy way-written in Chinese. Sometimes I helped write down poems that Molly composed in her journal. Her innocent child's world can be seen through her playful way of using her heritage language:

“放屁，是臭臭的哭哭 (Fart is the crying of poop).

雾, 就是草地上的云彩 (Fog is cloud flowing on the grass).

(Molly's poems, 2019)

LEARNing Landscapes | Spring 2021, Vol. 14 No. 1 | 37 
The purpose of practicing writing in her heritage language goes beyond mastery of composing the correct characters and/or phrases. I also engaged Molly and Luna in emergent writing in our home to introduce the knowledge of sound/symbol connections, the conventions of print, and accessing and conveying meaning through print mode in the heritage language system. Drawing on my immigrant parent knowledge, I intended to help the children construct meaning by making relevant cultural and linguistic connections with print (Goodman \& Goodman, 2014) in Chinese and their own lived experiences.

\section{Retelling My Stories: Possibilities of Heritage Language Education}

In my everyday experiences of practicing heritage language with my young daughters in our home context, new knowings emerged from the fragmented pieces of my old knowings (Anzaldua, 1987/1999). My experiences alongside my children during their language-learning journey challenged me to explore a range of philosophical, theoretical, and practical considerations relating to my role as an immigrant parent and as the first and most important teacher in my daughters' heritage language education. Through inquiry into my reconstructed narrative, I came to embrace theories of parent knowledge, family literacy, and bilingual education and transform the knowledge and information into my pedagogy of language learning in a home context. Shaped by these experiences, I composed a new life narrative alongside my daughters in our home setting, and generated new puzzles and wonderings for the possibilities of immigrant children's heritage language education.

I was keenly aware that there is an extensive body of literature on bilingual education from the eyes of educators, but no corresponding body of literature from the eyes of parents. Few studies have examined the specific strategies and practices that immigrant parents employ, and the ways in which they allocate resources in their home context, to support heritage language development. As a result, how parents make language choices and how each language is used, taught, and practiced in immigrant homes remain largely unknown.

The intention in my autobiographical narrative inquiry is to show poignantly that immigrant parents' efforts in their children's language education in the home context begins at birth, continues on a day-to-day basis, and probably will never end. By spending time living out a pedagogy in which parent knowledge shapes the teaching and learning of heritage language with my daughters in our home, I came to an understanding of my relational, intuitive, intimate, and practical knowledge I hold as a parent. I extended and expanded my children's heritage language knowledge through moments of intimate teaching, learning, and playing when we were engaged in conversations, story reading and acting, and emergent writing. As an immigrant parent, I intentionally brought my own parent knowledge of language and identity into the pedagogical language practices and made apparent to my children the values of maintaining our home language.

Keeping in mind Bruner's (1987/2004) statement, "In the end, we become the autobiographical narratives by which we 'tell about' our lives" (p. 694), I saw this becoming was indeed so for me and my daughters, and, I suspect, for a large community of immigrant families who may have adopted similar and/or 
The Pedagogical Practices of an Immigrant Parent: Maintaining Heritage Language in the Home Context

different practices to maintain and develop their home languages. I awakened to see that the value of our home language practices is the ground on which immigrant children can build a lifelong passion for their heritage language, the bridge to connect immigrant children with families, culture, history, and community, and help them find a sense of belonging and identity. As Monteagudo (2011) reminded us, "This capacity of narratives for imagining and constructing other worlds, and for trying to make them a reality, is an essential feature of the human capacity to transform our own selves as well as our social contexts" (p. 298). The stories of immigrant families, such as mine, can create new possibilities for repositioning parents and honoring their roles and efforts on the landscapes of immigrant children's schooling, as well as in their home learning contexts.

\section{References}

Agirdag, O. (2010). Exploring bilingualism in a monolingual school system: Insights from Turkish and native students from Belgian schools. British Journal of Sociology of Education, 31(3), 307-321. https://doi.org/10.1080/01425691003700540

Anzaldua, G. (1999). Borderlands/La frontera: The new mestiza. Aunt Lute. (Original work published 1987).

Avalos, M. A., Plasencia, A., Chávez, C., \& Rascón, J. (2007). Modified guided reading: Gateway to English as a second language and literacy learning. Reading Teacher, 61(4), 318-329.

https://doi.org/10.1598/RT.61.4.4

Baker, C. (2001). Foundations of bilingual education and bilingualism (3rd ed). Multilingual Matters.

Bruner, J. (2004). Life as narrative. Social Research, 71(3), 691-710. (Original work published 1987).

Byington, T., \& Kim, Y. (2017). Promoting preschoolers' emergent writing. YC Young Children, 72(5), 74-82. https://www.jstor.org/stable/90015861

Cantwell, M. (1993, November 2). Editorial notebook: 'I am a storyteller': An afternoon with Federico Fellini. The New York Times. https://www.nytimes.com/1993/11/02/opinion/editorial-notebook-i-am-astoryteller-an-afternoon-with-federico-fellini.html

Clandinin, D. J. (2013). Engaging in narrative inquiry. Routledge.

Clandinin, D. J. \& Caine, V. (2013). Narrative inquiry. In A. A. Trainor, \& E. Graue, (Eds.), Reviewing qualitative research in the social sciences (pp. 166-179). Routledge.

Clandinin, D. J., \& Connelly, F. M. (2000). Narrative inquiry: Experience and story in qualitative inquiry. Jossey Bass.

Clandinin, D. J., \& Rosiek, J. (2007). Mapping a landscape of narrative inquiry: Borderland spaces and tensions. In D. J. Clandinin (Ed.), Handbook of narrative inquiry: Mapping a methodology (pp. 35-75). Sage.

Collins, M. F. (2005). ESL preschoolers' English vocabulary acquisition from storybook reading. Reading Research Quarterly, 40(4), 406-408. www.jstor.org/stable/4151659 
Connelly, F. M., \& Clandinin, D. J. (1988). Teacher as curriculum planners: Narratives of experience. Teachers College Press.

Connelly, F. M., \& Clandinin, D. J. (2006). Narrative inquiry. In J. Green, S. Camilli, \& P. B. Elmore (Eds.), Handbook of complementary methods in education research (pp. 477-489). American Educational Research Association.

Coyle, Y., \& Mora, P. A. F. (2018). Learning a second language in pre-school: Using dramatized stories as a teaching resource. Didáctica: lengua y literatura, 30, 73.

https://pdfs.semanticscholar.org/893c/6abc359a07f96e520f4d12b84e1e2662560e.pdf

Cummins, J. (2017). Teaching minoritized students: Are additive approaches legitimate? Harvard Educational Review, 87(3), 404-425. https://doi.org/10.17763/1943-5045-87.3.404

Delpit, L. (1995). Other peoples' children: Cultural conflict in the classroom. The New Press.

Dennis, L. R., \& Votteler, N. K. (2013). Preschool teachers and children's emergent writing: Supporting diverse learners. Early Childhood Education Journal, 41(6), 439-446. https://doi.org/10.1007/s10643-

012-0563-4

Dixon, L. Q., \& Wu, S. (2014). Home language and literacy practices among immigrant secondlanguage learners. Language Teaching, 47(4), 414. https://doi.org/10.1017/S0261444814000160

Elbaz, F. (1981). The teacher's "practical knowledge": Report of a case study. Curriculum Inquiry, 11(1), 43-71. https://doi.org/10.1080/03626784.1981.11075237

Ewing, R., Callow, J., \& Rushton, K. (2016). Language and literacy development in early childhood. Cambridge University Press.

Glonek, K. L., \& King, P. E. (2014). Listening to narratives: An experimental examination of storytelling in the classroom. International Journal of Listening, 28(1), 32-46.

https://doi.org/10.1080/10904018.2014.861302

Goldenberg, C., Hicks, J., \& Lit, I. (2013). Dual language learners: Effective instruction in early childhood. American Educator, 37(2), 26-29.

https://link-gale-com.cyber.usask.ca/apps/doc/A420198220/EAIM?u=usaskmain\&sid=EAIM\&xid=68966f1 7

González, N., Moll, L. C., \& Amanti, C. (2005). Preface. In González, N., Moll, L. C., \& Amanti, C. (Eds.), Funds of knowledge: Theorizing practices in households, communities, and classrooms (pp. ix-xii). Lawrence Erlbaum Associates Publishers.

Goodman, K. S., \& Goodman, Y. M. (2014). Helping readers make sense of print: Research that supports a whole language pedagogy. In Israel, S. E., \& Duffy, G. G (Eds.), Handbook of research on reading comprehension (pp. 115-138). Routledge.

Guo, Y. (2012). Diversity in public education: Acknowledging immigrant parent knowledge.

Canadian Journal of Education, 35(2), 120-140.

https://www.jstor.org/stable/pdf/canajeducrevucan.35.2.120.pdf?casa_token=8bGVCHIdGLEAAAAA:85 0a_0QY4SD5oXkbeKk8a6fjw2BGVz_-Vvj_Vq8KES5BRZflt1fVuecLBg1zWL_rY3u-1T-

guOqwA5c2XgJUeX-uS6DBp1TKoQWm1idMWC0flo8sLQ 
The Pedagogical Practices of an Immigrant Parent: Maintaining Heritage Language in the Home Context

Hinton, L. (2001). Involuntary language loss among immigrants: Asian-American linguistic autobiographies. In J. E. Alatis, \& A. Tan (Eds.), Georgetown University round table on languages and linguistics (pp. 203-252). Georgetown University Press.

Kang, H. S. (2013). Korean-immigrant parents' support of their American-born children's development and maintenance of the home language. Early Childhood Education Journal, 41(6), 431-438. https://doi.org/10.1007/s10643-012-0566-1

Khan, M. (2018). O Canada, whose home and native land? An autobiographical narrative inquiry into the critical role of curriculum in identity affirmation [Unpublished doctoral dissertation]. University of Saskatchewan.

Kondo-Brown, K. (2010). Curriculum development for advancing heritage language competence: Recent research, current practices, and a future agenda. Annual Review of Applied Linguistics, 30, 24. https://doi-org.cyber.usask.ca/10.1017/S0267190510000012

Li, G. (2006). Biliteracy and trilingual practices in the home context: Case studies of Chinese-Canadian children. Journal of Early Childhood Literacy, 6(3), 359-385.

https://doi.org/10.1177/1468798406069797

Luo, S. H., \& Wiseman, R. L. (2000). Ethnic language maintenance among Chinese immigrant children in the United States. International Journal of Intercultural Relations, 24(3), 307-324.

https://doi.org/10.1016/S0147-1767(00)00003-1

Mills, J. (2001). Being bilingual: Perspectives of third generation Asian children on language, culture and identity. International Journal of Bilingual Education and Bilingualism, 4(6), 383-402.

https://doi.org/10.1080/13670050108667739

Mokhtar, N. H., Halim, M. F. A., \& Kamarulzaman, S. Z. S. (2011). The effectiveness of storytelling in enhancing communicative skills. Procedia-Social and Behavioral Sciences, 18, 163-169.

https://core.ac.uk/reader/82450422

Monteagudo, J. G. (2011). Jerome Bruner and the challenges of the narrative turn: Then and now. Narrative Inquiry, 21(2), 295-302. https://doi.org/10.1075/ni.21.2.07gon

Nunez, G. (2019). A home-based language intervention with Mexican immigrant mothers and their children [Doctoral dissertation, University of Illinois at Chicago].

https://indigo.uic.edu/articles/A_Home-

Based_Language_Intervention_with_Mexican_Immigrant_Mothers_and_Their_Children/10865930/files/ 19369715.pdf

Oh, J. S. (2003). Raising bilingual children: Factors in maintaining a heritage language (Publication No. 3089043) [Doctoral dissertation, University of California]. ProQuest Dissertations Publishing.

Pham, G., \& Tipton, T. (2018). Internal and external factors that support children's minority first language and English. Language, Speech, and Hearing Services in Schools, 49(3), 595-606.

https://doi.org/10.1044/2018_LSHSS-17-0086

Polanyi, M. (1958). Personal knowledge: Towards a post-critical philosophy. University of Chicago Press.

Pushor, D. (2008, March). Parent knowledge, acKNOWLEDGing parents [Paper presentation]. Annual Meeting of the American Educational Research Association, New York, NY. 
Pushor, D. (2015). Conceptualizing parent knowledge. In Pushor, D., \& the Parent Engagement Collaborative II (Eds.), Living as mapmakers: Charting a course with children guided by parent knowledge (pp. 1-20). Sense Publishers.

Roessingh, H. (2014). Grandma's soup: Thematic instruction for dual language learners. YC Young Children, 69(4), 86.

http://cyber.usask.ca/login?url=https://www.proquest.com/docview/1621401718?accountid=14739

Rowe, D. W., \& Neitzel, C. (2010). Interest and agency in 2-and 3-year-olds' participation in emergent writing. Reading Research Quarterly, 45(2), 169-195. https://doi.org/10.1598/RRQ.45.2.2

Scheele, A. F., Leseman, P. P., \& Mayo, A. Y. (2010). The home language environment of monolingual and bilingual children and their language proficiency. Applied Psycholinguistics, 31(1), 117-140. https://doi-org.cyber.usask.ca/10.1017/S0142716409990191

Sénéchal, M., \& LeFevre, J. (2002). Parent involvement in the development of children's reading skill: A five-year longitudinal study. Child Development, 73, 445-460. https://doi.org/10.1111/1467-8624.00417

Sénéchal, M., LeFevre, J., Thomas, E. M., \& Daley, K. E. (1998). Differential effects of home literacy experiences on the development of oral and written language. Reading Research Quarterly, 33, 96-116. https://doi.org/10.1598/RRQ.33.1.5

Shneidman, L. A., \& Goldin-Meadow, S. (2012). Language input and acquisition in a Mayan village: How important is directed speech? Developmental Science, 15, 659-673.

https://doi.org/10.1111/j.1467-7687.2012.01168.x

Strekalova-Hughes, E., \& Wang, X. C. (2019). Perspectives of children from refugee backgrounds on their family storytelling as a culturally sustaining practice. Journal of Research in Childhood Education, 33(1), 6-21. https://doi.org/10.1080/02568543.2018.1531452

Suárez-Orozco, C. (2001). Afterword: Understanding and serving the children of immigrants. Harvard Educational Review, 71(3), 579-590.

http://cyber.usask.ca/login?url=https://search.proquest.com/docview/212286991 ?accountid=14739

Uccelli, P., \& Páez, M. M. (2007). Narrative and vocabulary development of bilingual children from kindergarten to first grade: Developmental changes and associations among English and Spanish skills. Language, Speech, and Hearing Services in Schools, 38(3), 225-236.

https://doi.org/10.1044/0161-1461(2007/024)

Vaish, V. (2019). Translanguaging pedagogy for simultaneous biliterates struggling to read in English. International Journal of Multilingualism, 16(3), 286-301.

https://doi.org/10.1080/14790718.2018.1447943

Wong Fillmore, L. (2000). Loss of family languages: Should educators be concerned? Theory Into Practice, 39(4), 203-210. https://doi.org/10.1207/s15430421tip3904_3 


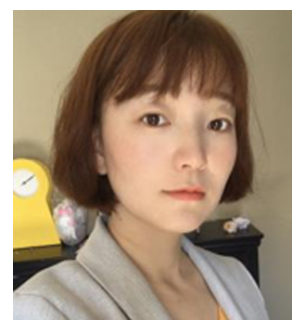

Emma Chen is a doctoral student in Curriculum Studies at the University of Saskatchewan, engaged in a narrative inquiry into immigrant children's heritage language education, in the context of home, community, and school. Originally from China, Emma is an immigrant parent to two young bilingual children who speak both English and Chinese. Every day, Emma walks alongside her little girls exploring the wonderful (and sometimes challenging) worlds of language and culture. 